\title{
The noise climate at the time of SARS-CoV-2 VIRUS/COVID-19 disease in Athens - Greece: The case of Athens International Airport and the Athens Ring Road (Attiki Odos)
}

https://doi.org/10.1515/noise-2020-0014

Received Jun 16, 2020; accepted Aug 17, 2020

Abstract: In Wuhan city, China, there was an influx of cases of pneumonia. On 9 January 2020, the Health $\mathrm{Au}$ thorities of China announced that it is a new strain of coronavirus (COVID-19). Coronaviruses are a group of viruses that usually cause respiratory infections with varying severity in humans and animals. After the announcement of the first deaths because of COVID-19 disease, all over the world, as in Greece, concerted efforts are being made to tackle the spread of SARS-CoV-2 virus and the relevant COVID-19 disease. To delay and limit the transmission of the virus, national governments implemented strict restrictions on the daily transportation of citizens as well as the supply of non-essential goods. These restrictions caused rapid changes in the daily life of residents mainly in urban areas and significantly affected the noise climate. This paper extensively presents the acoustic recordings of the permanent noise monitoring stations being installed at Athens International Airport and Attica Tollway for the years 2018, 2019 and 2020. The compared graphs indicate the strong influence of the new conditions and restrictions applied due to the COVID-19 disease on the daily noise climate both at international airport and on major motorway.

Keywords: noise climate, monitoring stations, COVID-19, motorway, airport

\footnotetext{
^Corresponding Author: Vassiliki Zafiropoulou: Laboratory of Transportation Environmental Acoustics, University of Thessaly, Pedion Areos, 38334 Volos, Greece; Email: vaszafir@uth.gr Konstantinos Vogiatzis, Georgia Gerolymatou: Laboratory of Transportation Environmental Acoustics, University of Thessaly, Pedion Areos, 38334 Volos, Greece

Dimitrios Dimitriou, Aristeidis Konstantinidis: Athens International Airport S.A., Greece

Bill Halkias, Aristofanis Papadimitriou: Attikes Diadromes S.A., 41,9 km Attiki Odos Motorway, Paiania 19002 Greece
}

\section{Introduction - Presentation of the infrastructure}

The Athens International Airport "Eleftherios Venizelos", also known as Athens Airport and commonly initialized as AIA, is the biggest and most crowded international airport in Greece that it serves not only its capital, the city of Athens, but also the Attica region [1, 2]. In addition, the Athens Airport constitutes the southern gateway of Europe to the world and one of the largest infrastructure projects in Greece with an intense entrepreneurship but also social character [3, 4] (see Figure 1).

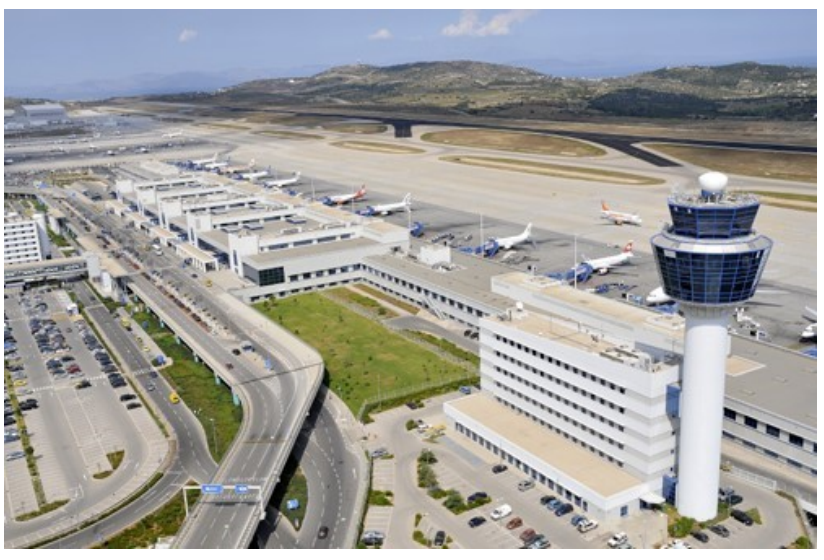

Figure 1: Athens International Airport (AIA)

Aircraft noise is undoubtedly one of the main and an inevitable environmental issue in residential areas around the Airport and underneath the flight paths. For this purpose, considerable efforts are being made to limit its impact by taking measures to reduce annoyance and keeping aircraft noise to the minimum possible levels. To protect the acoustic environment, Athens Airport monitor aircraft noise yearly through the installed Noise Monitoring Sys- 
Table 1: Noise monitoring system of AIA

\begin{tabular}{lcc}
\hline Station & Area & Location \\
\hline NMT 1 & Airport & Fire station \\
MNT 2 & Vorineza-Artemis & Private space \\
NMT 3 & Agios loannis - Artemis & Private space \\
NMT 5 & Artemis & Artemis 1 \\
& & Primary School \\
NMT 6 & Agios Nikolaos - Artemis & Sports center \\
NMT 8 & Markopoulo & Markopoulo High \\
& & School \\
\hline
\end{tabular}

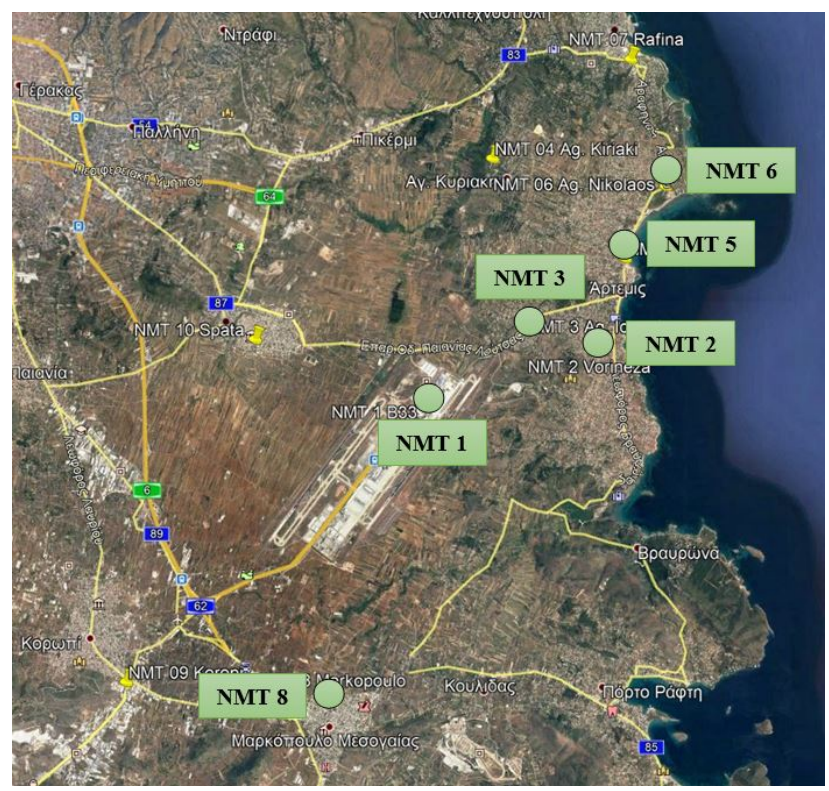

Figure 2: Noise monitoring system of AIA

tem (NOMOS) which provide a detailed profile of aircraft noise in the residential areas near flight paths. In particular, the NOMOS consists of one mobile and ten permanent stations (a high-tech system supplied by Bruel \& Kjaer) of which the most representative for the aircraft movements in the COVID-19 disease period and taking into consideration the relative measures to reduce the spread of the virus are shown in Table 1 and Figure 2. The NOMOS from the beginning of its operation ensures the continuous monitoring of noise indicators in the wider area of the airport and automatic correlation of noise levels with specific aircraft movements.

Another major transportation project that connects the city of Athens with the Athens Airport is the Attiki Odos (Athens Ring Road e.g. Attica Tollway - see Figure 3). It is a modern motorway extending along $70 \mathrm{~km}$. It constitutes the ring road of the greater metropolitan area of Athens

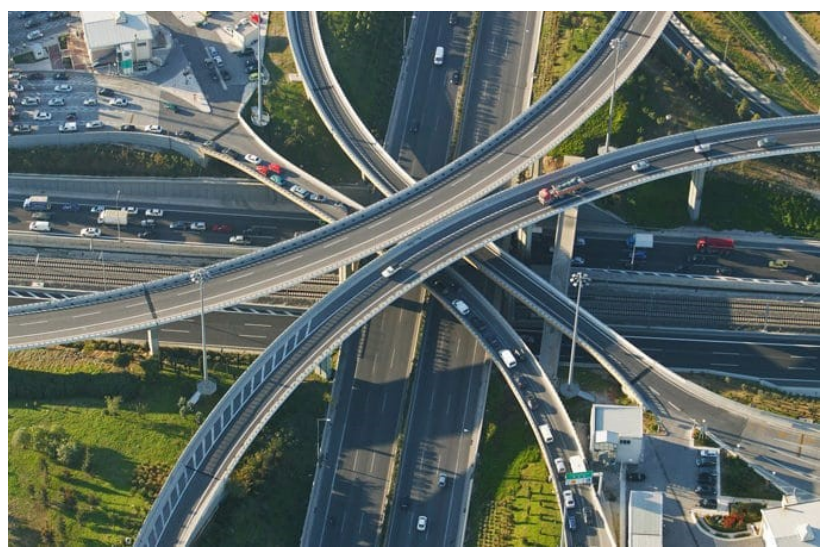

Figure 3: Attiki Odos - The main Athens North Entrance Metamorphosis 3 level IC

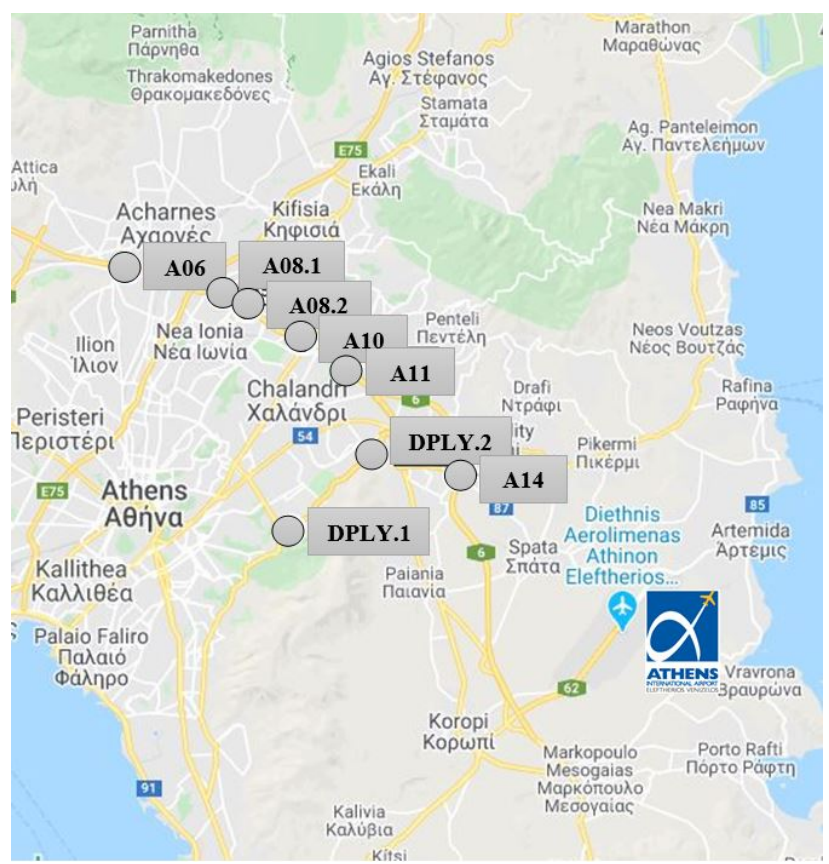

Figure 4: Locations of noise monitoring system of Attica Tollway

and the backbone of the urban and semi urban road network of the whole Attica Prefecture.

It is an urban motorway, with two separate directional carriageways, each consisting of 3 lanes and an emergency lane (hard shoulder) [5]. Noise as well as the emission of air pollutants are two severe problems that need to be addressed by those responsible for the maintenance and operation of the motorway. For this purpose, 8 permanent noise monitoring stations have been installed at selected locations of the motorway since $2003[6,7]$. Table 2 hereafter presents the system of permanent environmental road noise monitoring stations of Attica Tollway (equipped with CUBE noise monitoring stations by ACOEM-01dB). 
Table 2: Noise monitoring system of Attica Tollway

\begin{tabular}{cccc}
\hline $\begin{array}{c}\text { Description of } \\
\text { Station }\end{array}$ & $\begin{array}{c}\text { Localization (Attiki Odos } \\
\text { geographical section) }\end{array}$ & $\begin{array}{c}\text { Description of } \\
\text { station }\end{array}$ & $\begin{array}{c}\text { Localization (Attiki Odos } \\
\text { geographical section) }\end{array}$ \\
\hline Cube 11003 & A06 & Cube 11032 & A11 \\
Cube 11008 & A08.1 & Cube 11034 & A14 \\
Cube 11011 & A08.2 & Cube 11065 & DPLY.1 \\
Cube 11013 & A10 & Cube 11035 & DPLY.2 \\
\hline
\end{tabular}
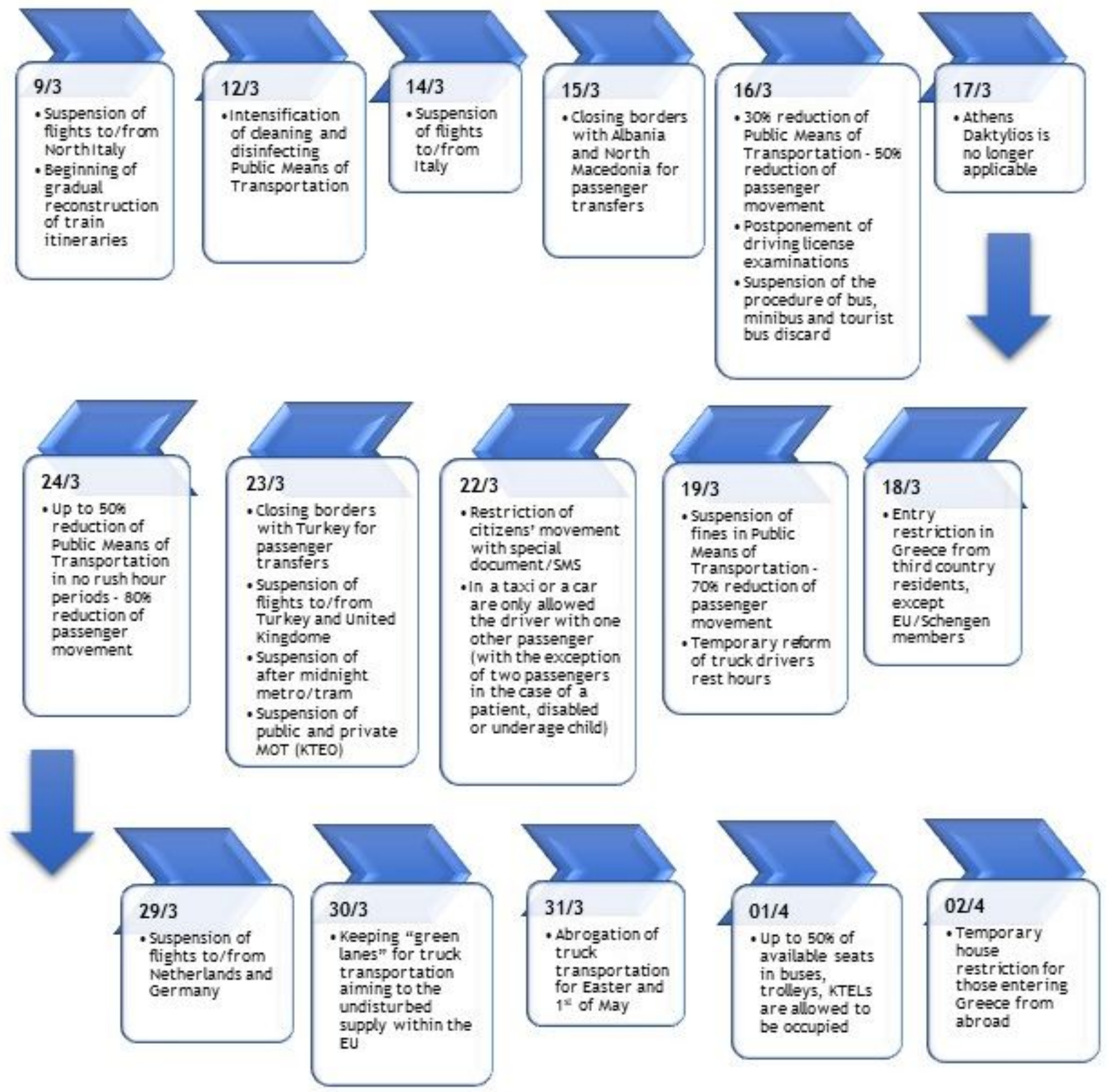

Figure 5: Time history of measures and restrictions enforced in transportation due to COVID-19 pandemic 
From 2003 until today, the noise monitoring system operates continuously, and it was upgraded with new state-of-the-art permanent monitoring stations. Figure 4 shows the locations of the permanent noise monitoring stations.

In order to protect the population that resides in the proximity of both the Airport and the Motorway and is exposed to high levels of environmental noise [8], which has been shown to cause severe annoyance and disturbance to residents [9], the recent maximum permissible limits as per the National legislation and according to the European Directive 2002/49/EC have been implemented [10] for both airport [11] and road environmental noise indicators, $\mathrm{L}_{d e n}$ (24-hour index) and $\mathrm{L}_{\text {night }}$ (8-hour index), defined as follows [12]:

a) Noise index $\mathrm{L}_{\text {den }}$ (24-hour) $\leq 70 \mathrm{~dB}(\mathrm{~A})$,

b) Noise index $\mathrm{L}_{\text {night }}$ (8-hour) $\leq 60 \mathrm{~dB}(\mathrm{~A})$.

\section{The pandemic of COVID-19 disease}

The pandemic of the new coronavirus 2019 appeared and spread in Greece from 26 February 2020 onwards. Following the confirmation of the first three cases in Greece, initially on 27 February 2020 all carnival and other cultural events were cancelled in the country and by 10 March, there had been a total of 89 cases in the country mainly related to travelers from Italy as well as a group of pilgrims who had travelled to Israel and Egypt and their contacts. Health and state authorities issued recommendations and guidelines to protect the population, while the measures taken included the individual closure of schools and the suspension of cultural and artistic events in the affected areas. However, after 10 March, due to the outbreak of the virus in various parts of the country and due to the noncompliance with the restriction measures by the citizens, it was decided to close all educational structures in the country and on 13 March, the suspension of the operation of cafes, bars, museums, shopping centers, sports facilities and restaurants. On March $16^{\text {th }}$, all shops were closed, two villages in Kozani were quarantined, while it was decided to suspend all functions of every doctrine and religion. On 23 March, significant restrictions were imposed on the movement of citizens throughout the territory, except for exceptions for those on the road to and from work, moving to obtain essential goods or medicines, or visiting a doctor or person in need of assistance. On 4 April it was decided to extend the restrictions, which eventually lasted until 4
May. The purpose of this work is to assess the noise levels of permanent monitoring stations installed at both the airport and the motorway and then to compare the results of the recordings of the years 2018, 2019 and 2020. The goal is to establish the influence of the pandemic (COVID-19 disease) on the noise climate in the period from 8 March to 30 April 2020 where the special restrictive measures were taken on the transport of citizens, changes concerning the opening hours of shops, the closure of schools and shops providing non-essential products, work of citizens from their home to avoid the transmission of the pandemic. All measures and relevant restrictions regarding transportation are analytically shown in Figure 5 (in chronological order).

\section{The influence of COVID-19 disease: Road traffic noise}

The emergence of the pandemic had a serious influence on population movements both in the center and in the suburbs of cities due to the restrictive measures decided on to tackle COVID-19 disease. Figure 6 hereafter indicates the number of daily coronavirus cases recorded at national level (daily updates from https://www.civilprotection.gr/ el).

In the case of Attica Tollway, there was a remarkable decrease in traffic flows for the period between 8 March and 30 April 2020 (Figure 7) which concerns the entire motorway. The fluctuation of daily traffic volume in relation to the number of coronavirus cases in Greece is presented hereafter. The relevant curve expresses the number of coronavirus cases increased in normal vehicle traffic conditions and then gradually normalized tending to stabilize after implementing restrictive measures.

The traffic data for the period from 9 March to 30 April of the years 2018, 2019 and 2020 for all monitoring stations are presented hereafter as per the operation and maintenance services data. For the correct superimposition of all year graphs, the Orthodox Easter 2020 WE was set as the reference WE for all years.

The figures above draw some general conclusions:

- The daily traffic volumes corresponding to the years 2018 and 2019 are quite similar with limited variations

- A significant reduction in traffic volume is observed in the period under consideration of the year 2020 compared to previous years due to the restrictions imposed because of COVID-19 disease 


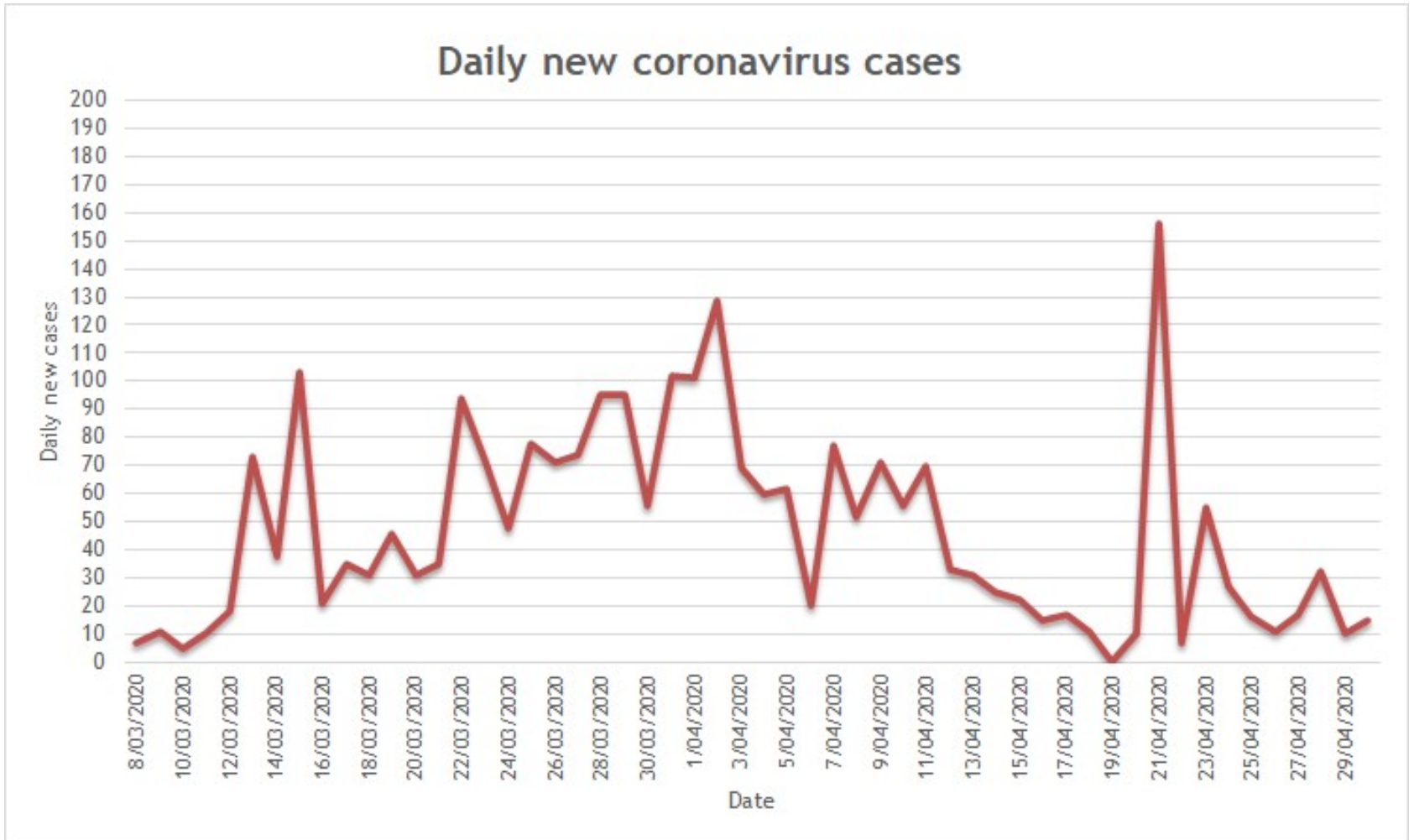

Figure 6: Daily new coronavirus cases

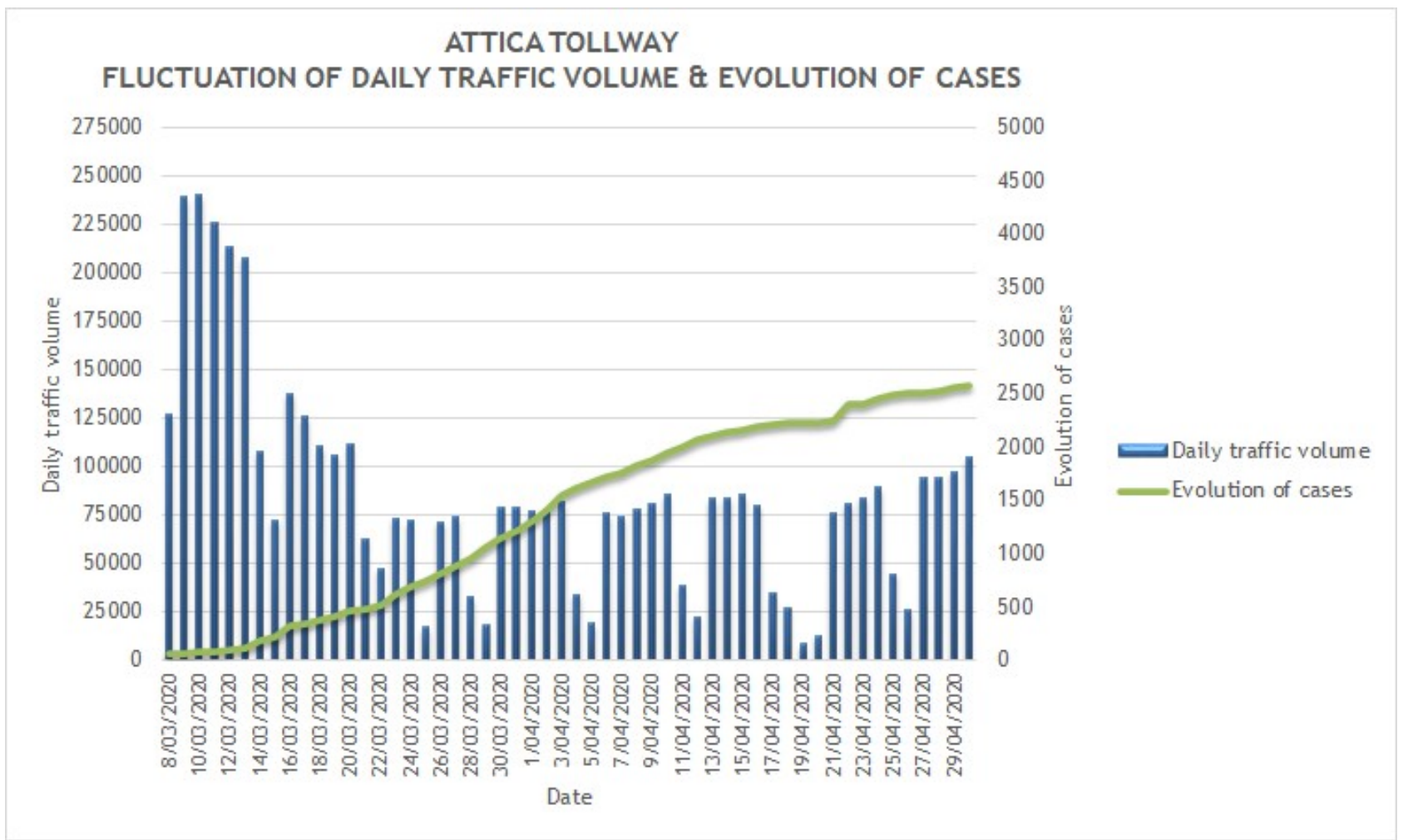

Figure 7: Fluctuation of daily traffic volume in relation to the evolution of cases 
DE GRUYTER

The noise climate at the time of SARS-CoV-2 VIRUS/COVID-19 disease in Athens

159

NOISE MONITORING STATION A06 - ATTIKI DOS FLUCTUATION OF DAILY TRAFFIC VOLUME FOR 2018-2019-2020 (COVID 19 Lockdown)

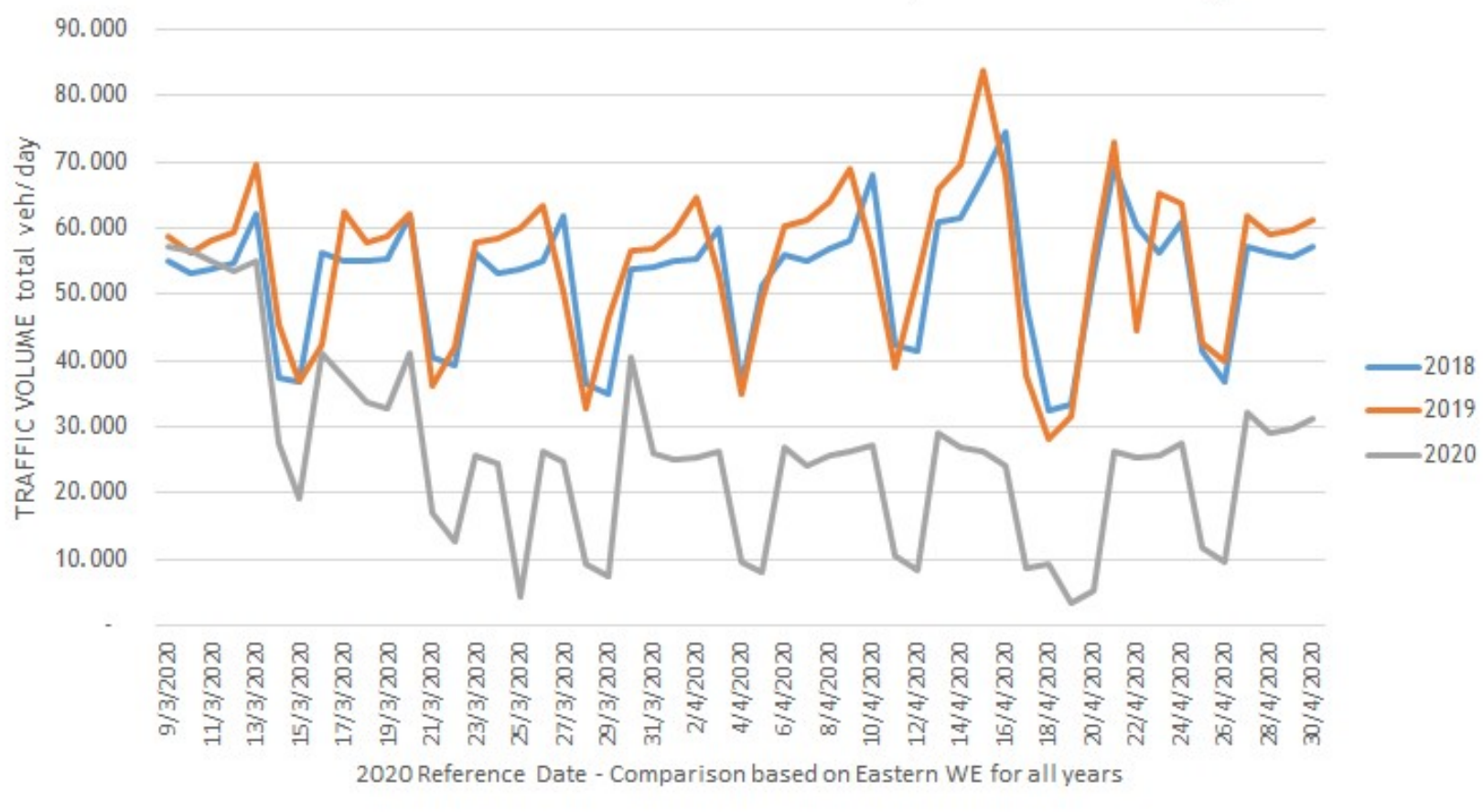

Figure Ba: Daily traffic volume - Noise monitoring station A06

NOISE MONITORING STATION A08.1 - ATTIKI DOS FLUCTUATION OF DAILY TRAFFIC VOLUME FOR 2018-2019-2020 (COVID 19 Lockdown)
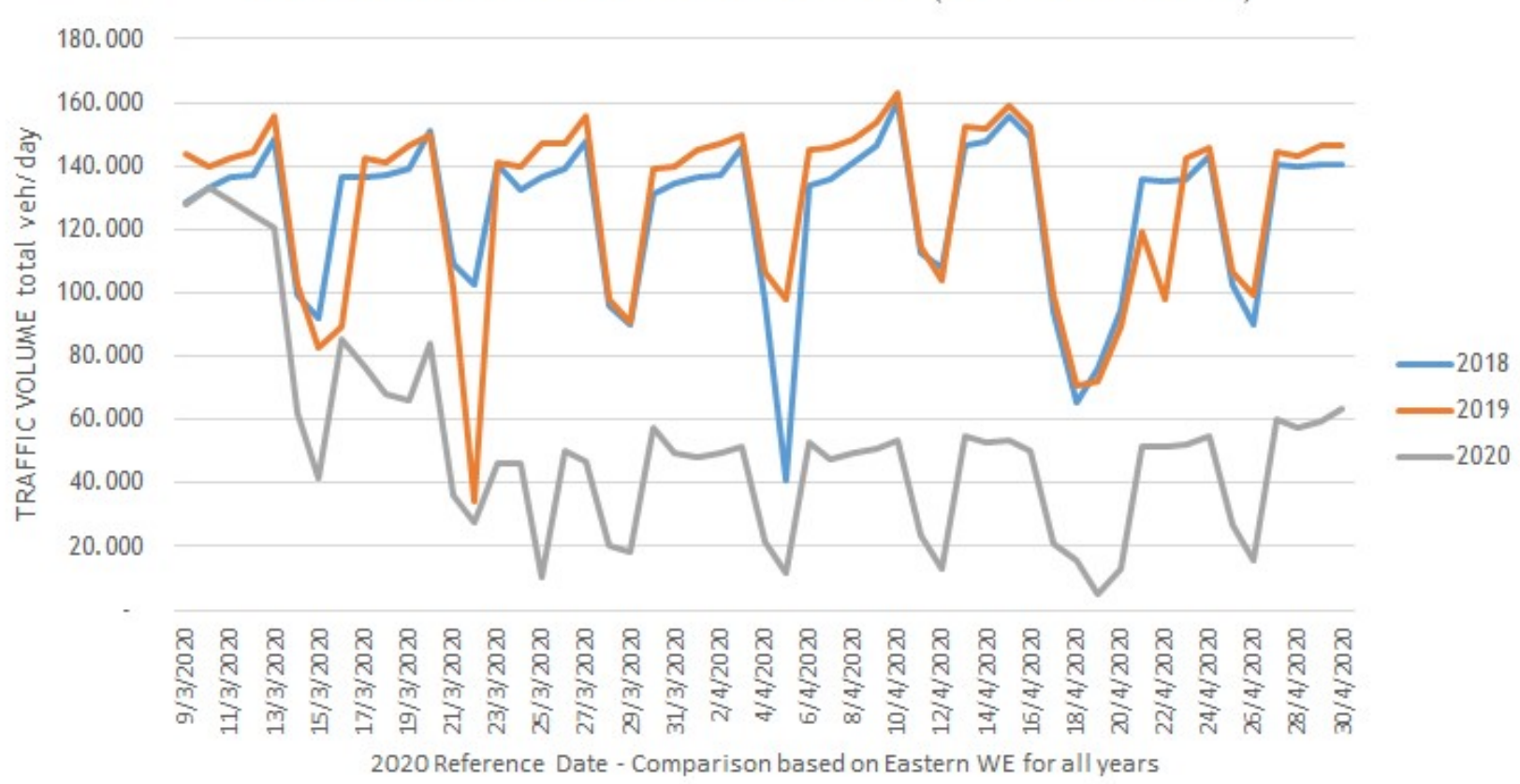

Figure Bb: Daily traffic volume - Noise monitoring station A08.1 


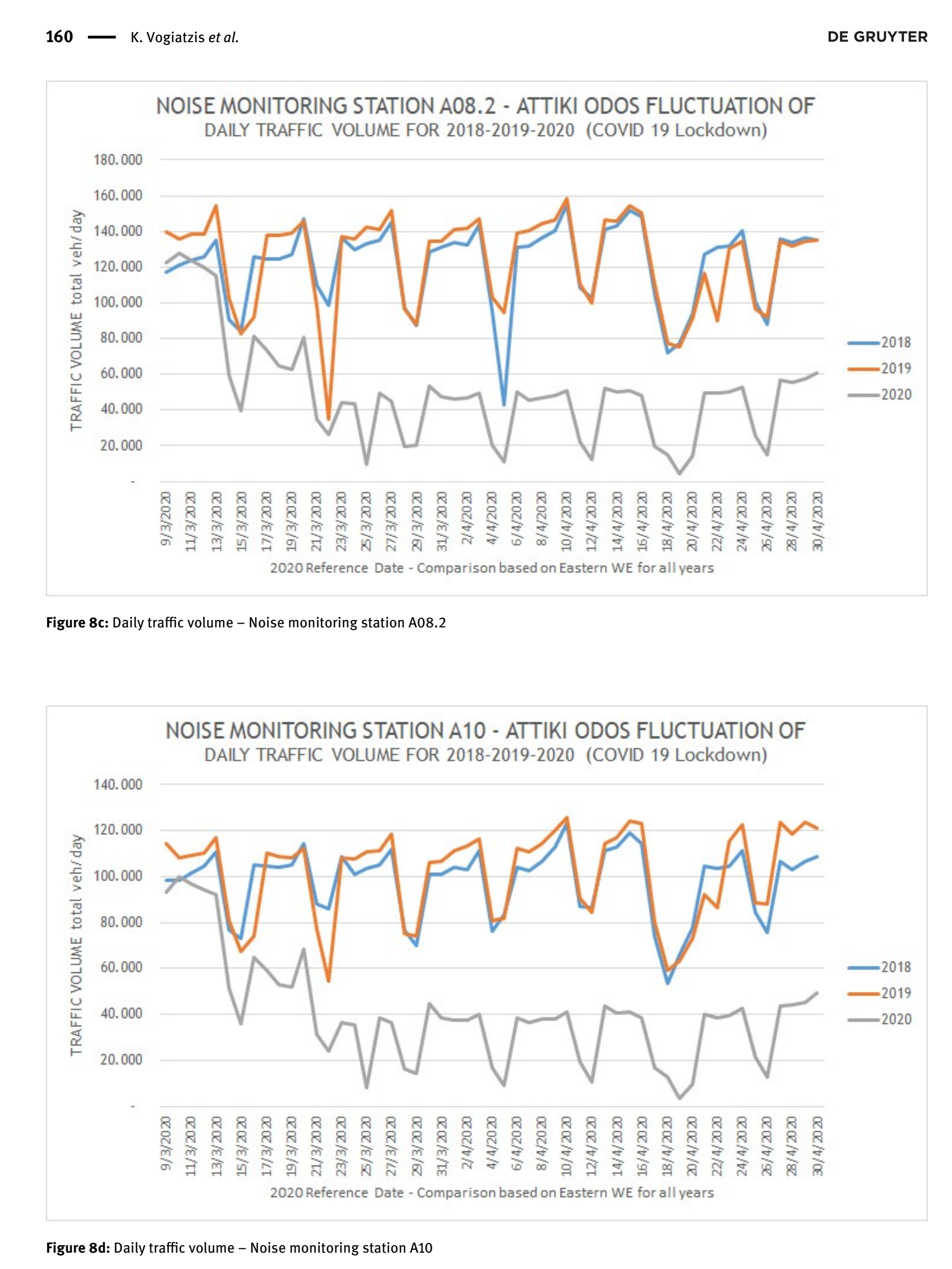




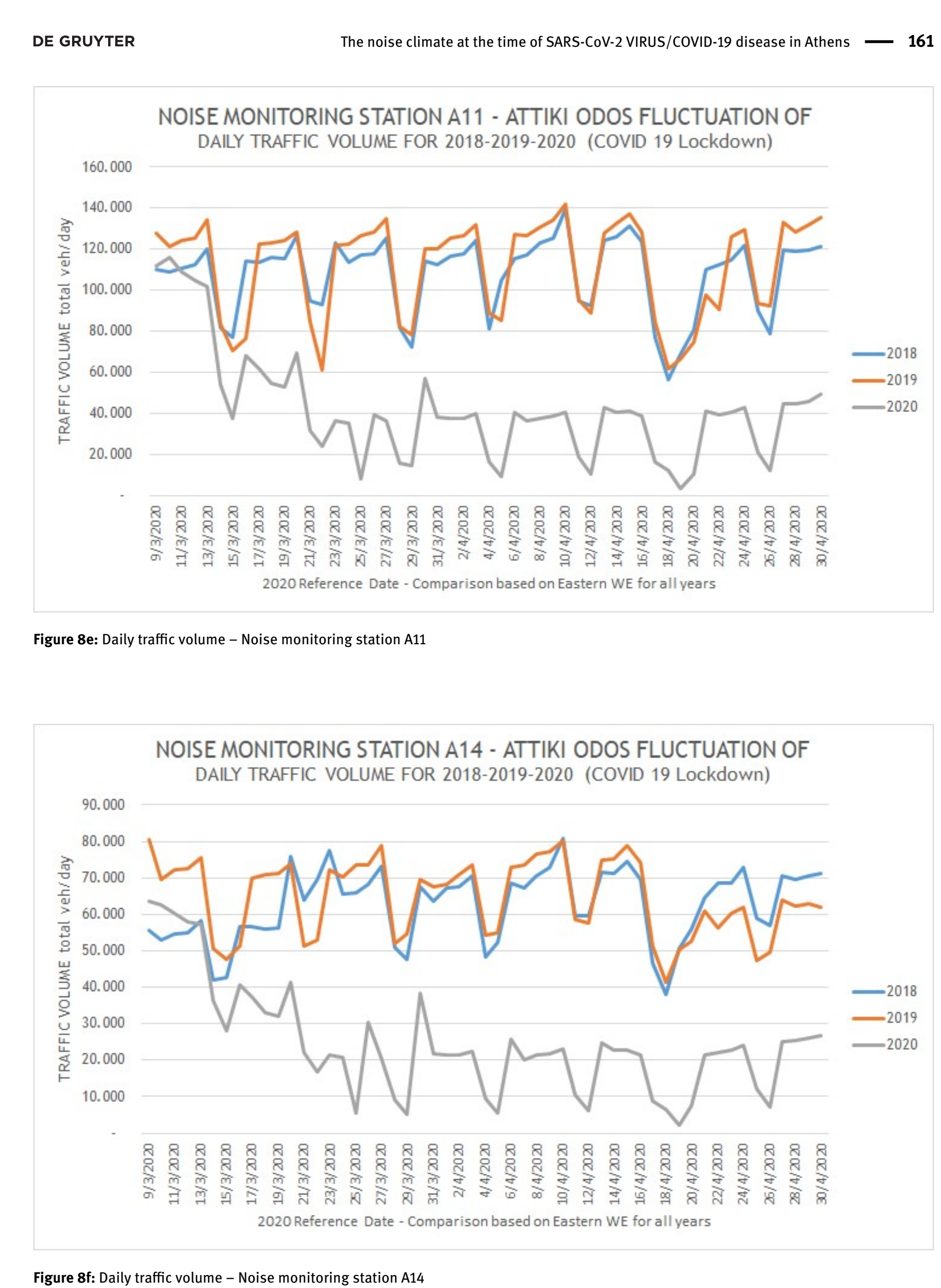


162

K. Vogiatzis et al.

DE GRUYTER

NOISE MONITORING STATION PLY. 1 - ATTIKI DOS FLUCTUATION OF DAILY TRAFFIC VOLUME FOR 2018-2019-2020 (COVID 19 Lockdown)

70.000

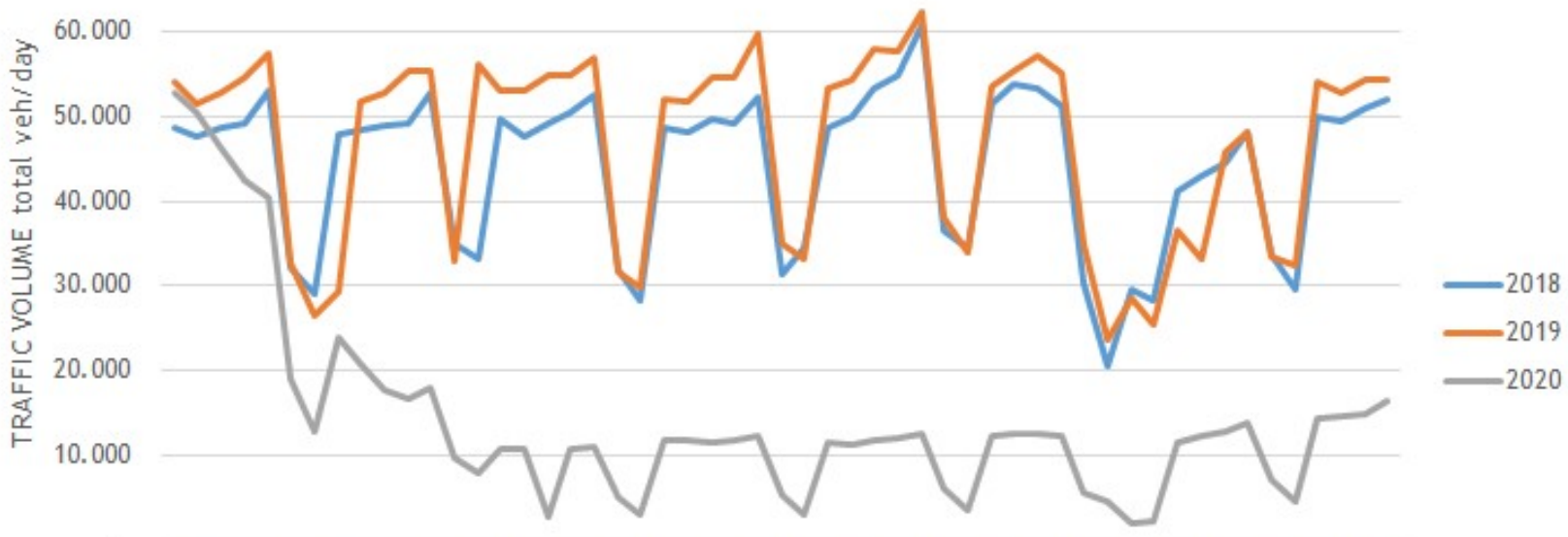

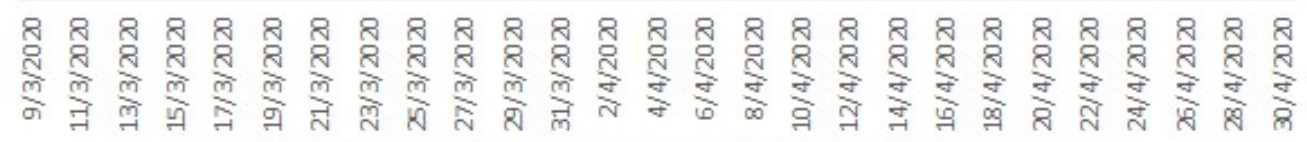

2020 Reference Date - Comparison based on Eastern WE for all years

Figure 8g: Daily traffic volume - Noise monitoring station DPLY.1

NOISE MONITORING STATION DPLY.2 - ATTIKI DOS FLUCTUATION OF DAILY TRAFFIC VOLUME FOR 2018-2019-2020 (COVID 19 Lockdown)

90.000

80.000

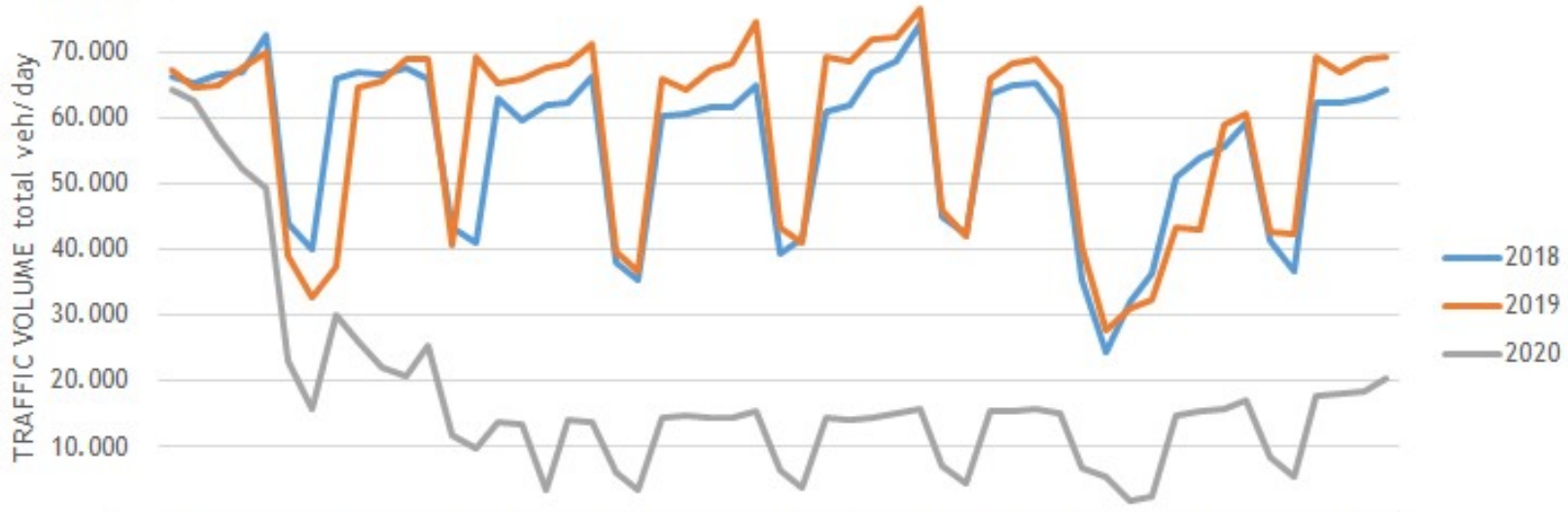

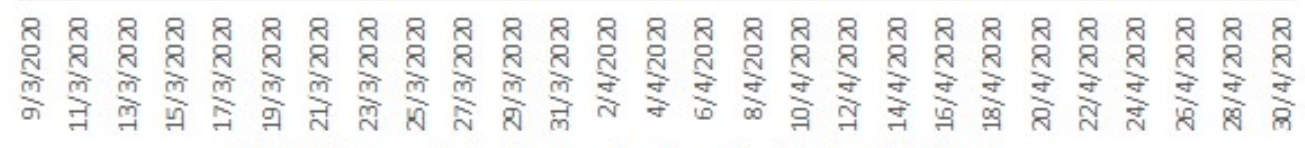

2020 Reference Date - Comparison based on Eastern WE for all years

Figure 8h: Daily traffic volume - Noise monitoring station DPLY.2 


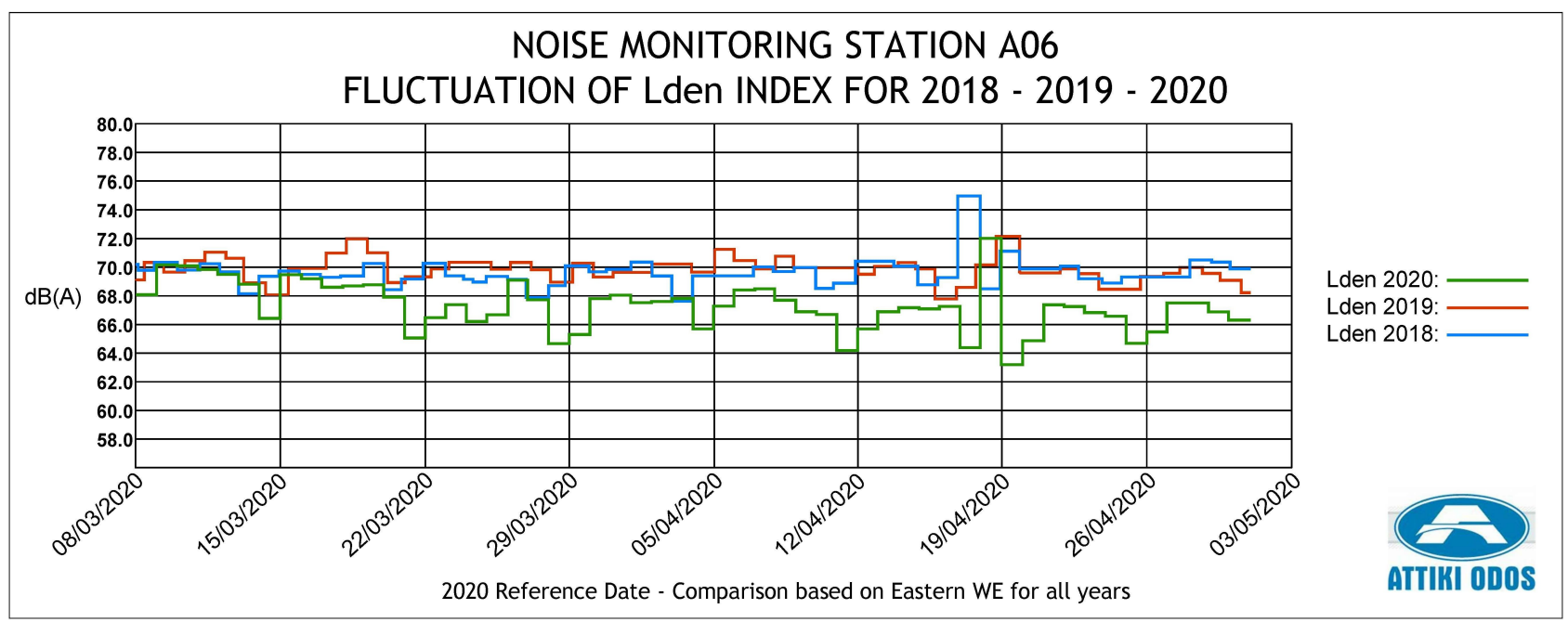

Figure 9a: Fluctuation of $\mathrm{L}_{d e n}$ index - Noise monitoring station A06

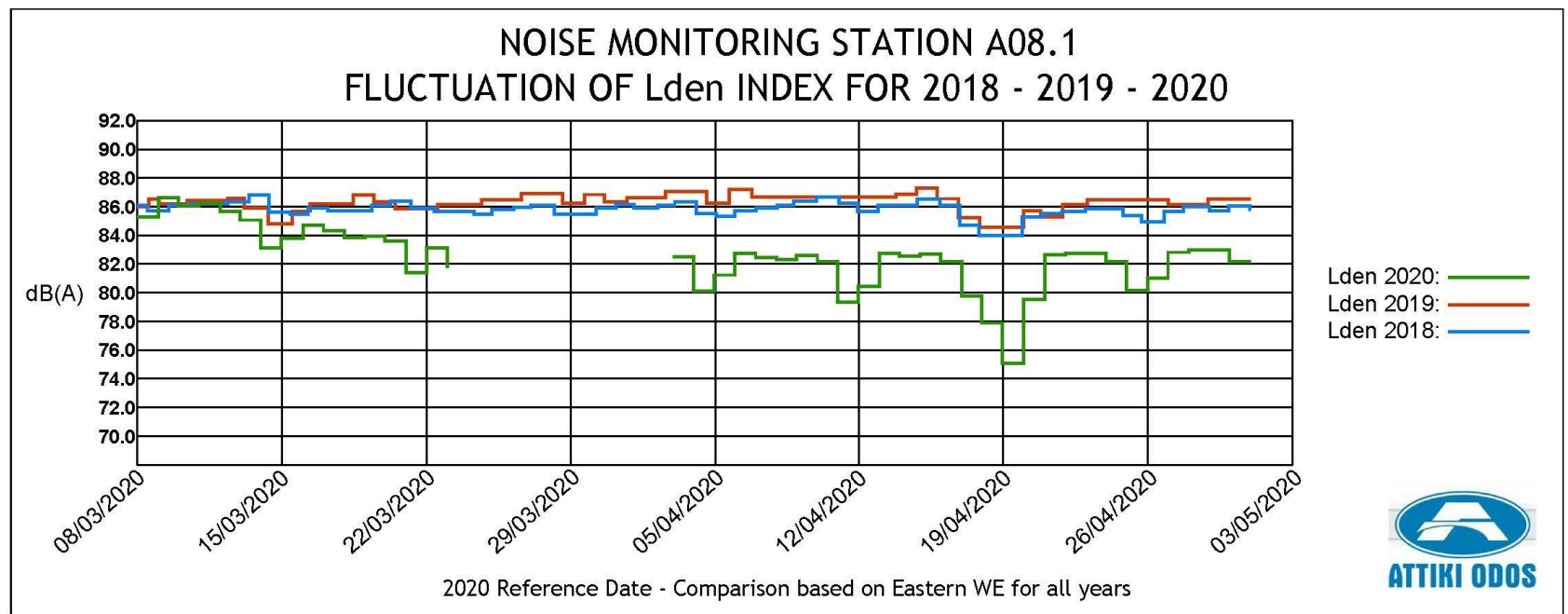

Figure 9b: Fluctuation of $\mathrm{L}_{d e n}$ index - Noise monitoring station A08.1

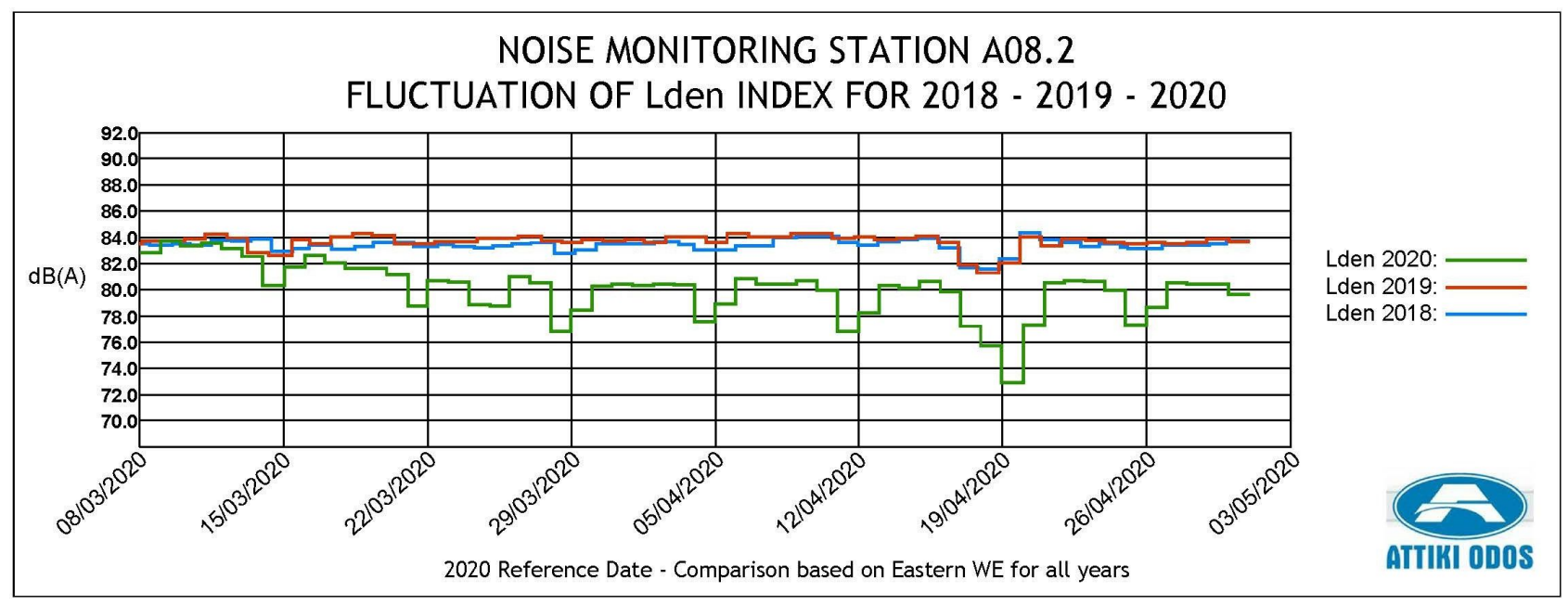

Figure 9c: Fluctuation of $\mathrm{L}_{\text {den }}$ index - Noise monitoring station A08.2 


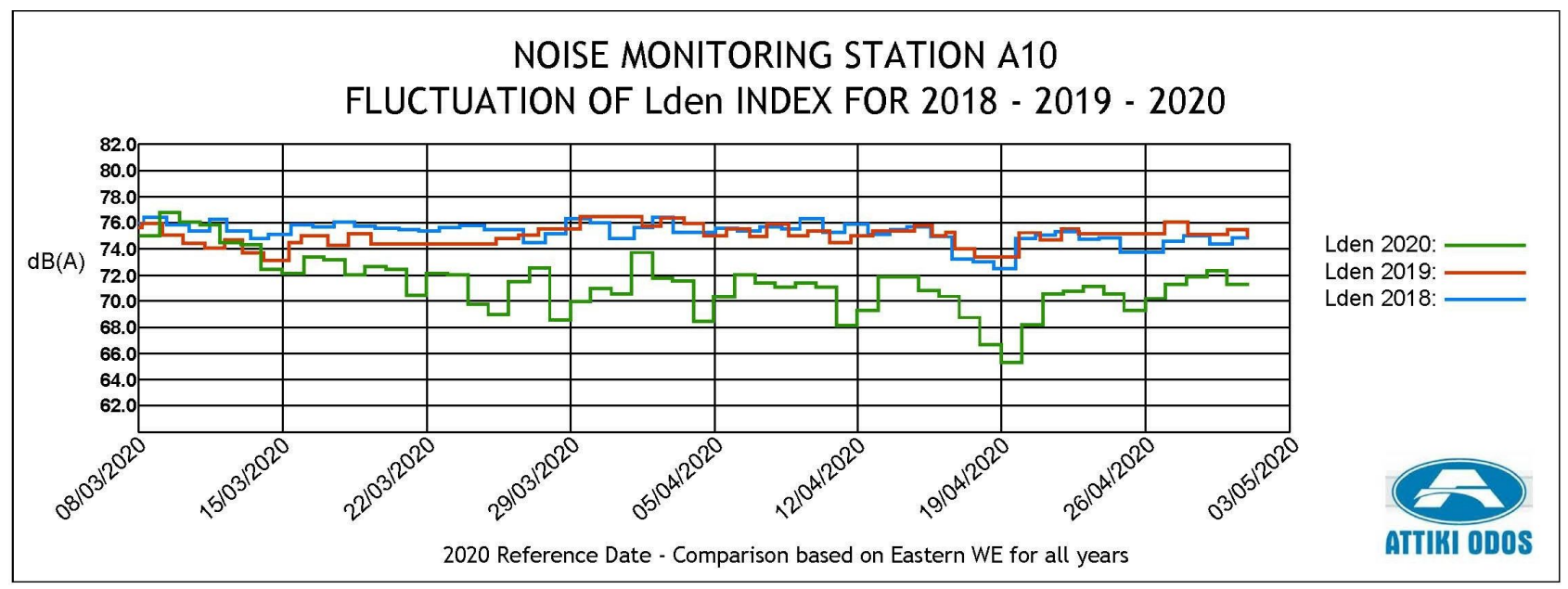

Figure 9d: Fluctuation of $\mathrm{L}_{d e n}$ index - Noise monitoring station $\mathrm{A} 10$

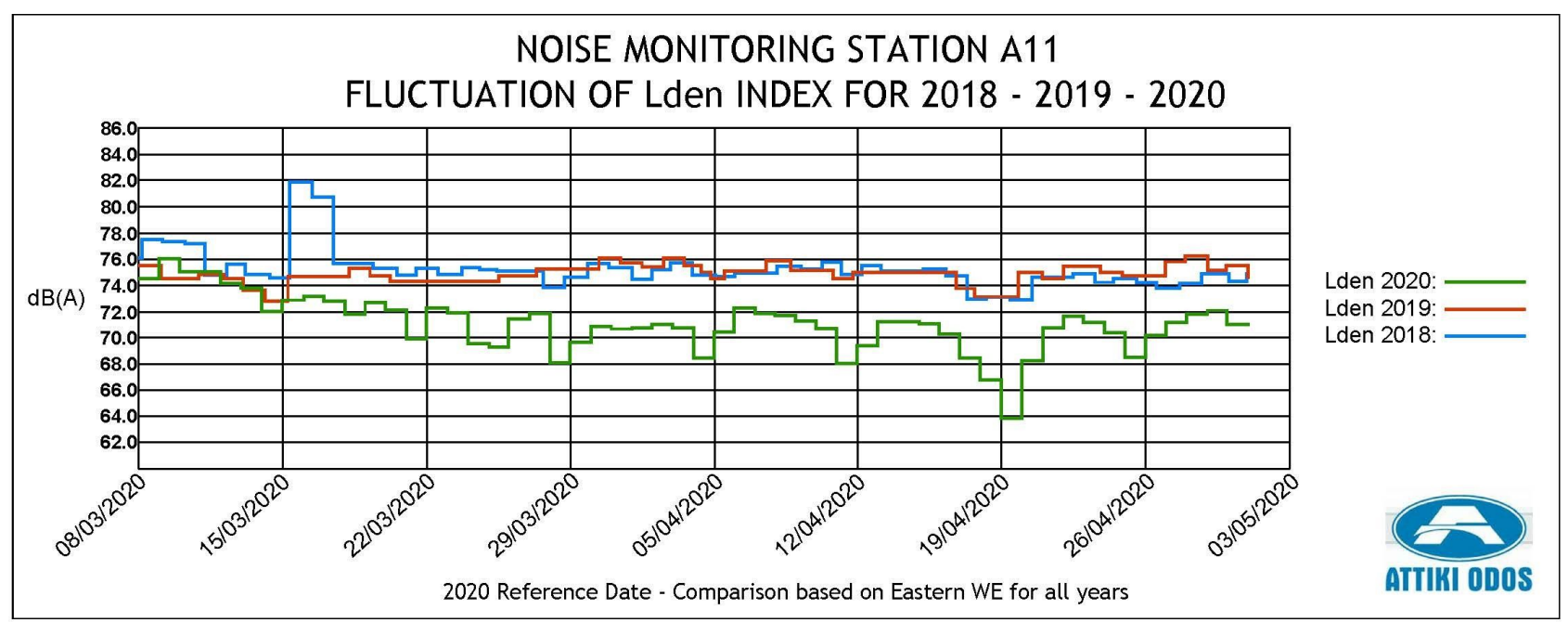

Figure 9e: Fluctuation of $\mathrm{L}_{d e n}$ index - Noise monitoring station A11

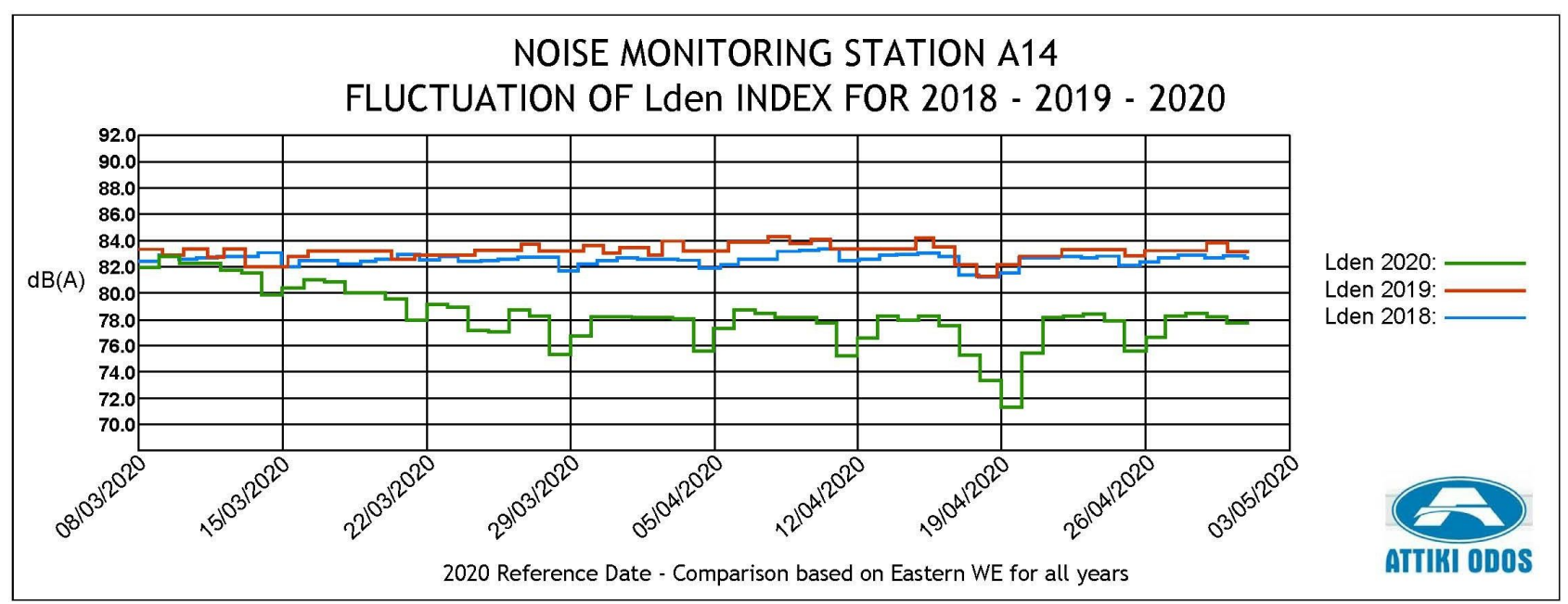

Figure 9f: Fluctuation of $\mathrm{L}_{d e n}$ index - Noise monitoring station A14 


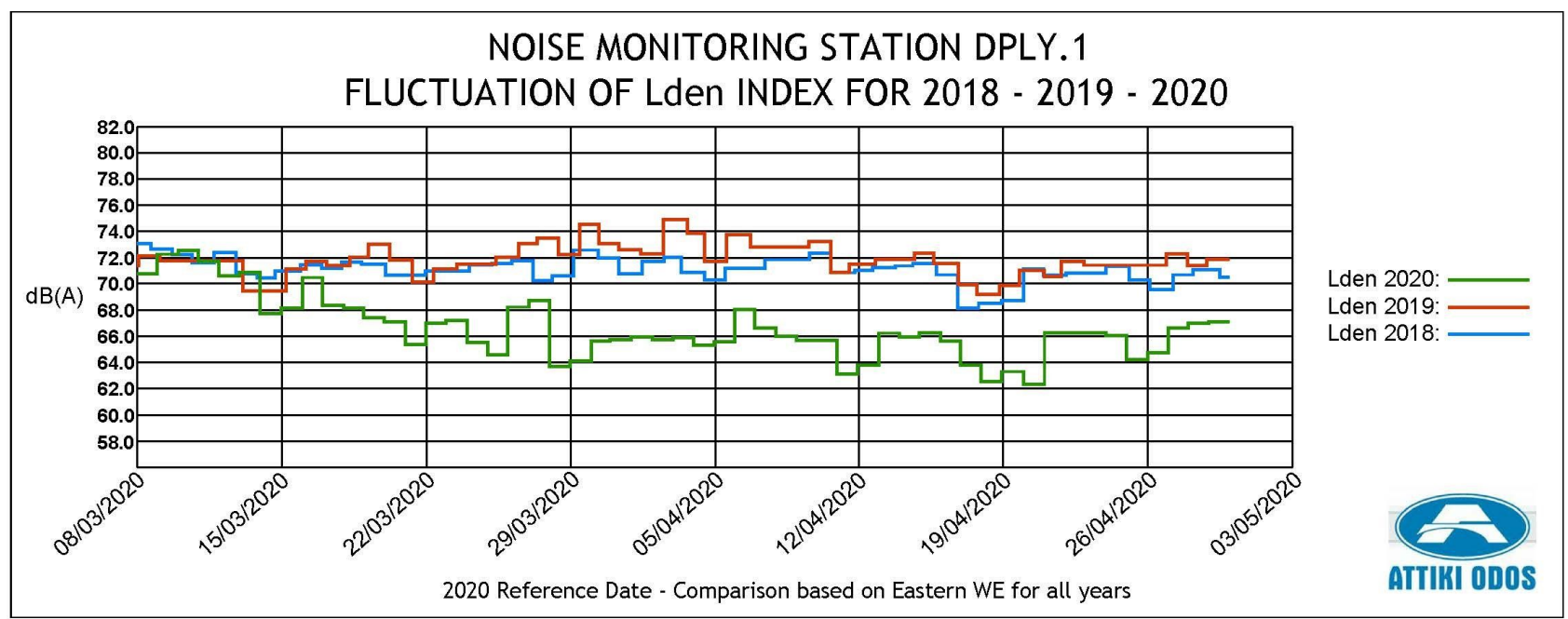

Figure 9g: Fluctuation of $\mathrm{L}_{d e n}$ index - Noise monitoring station DPLY.1

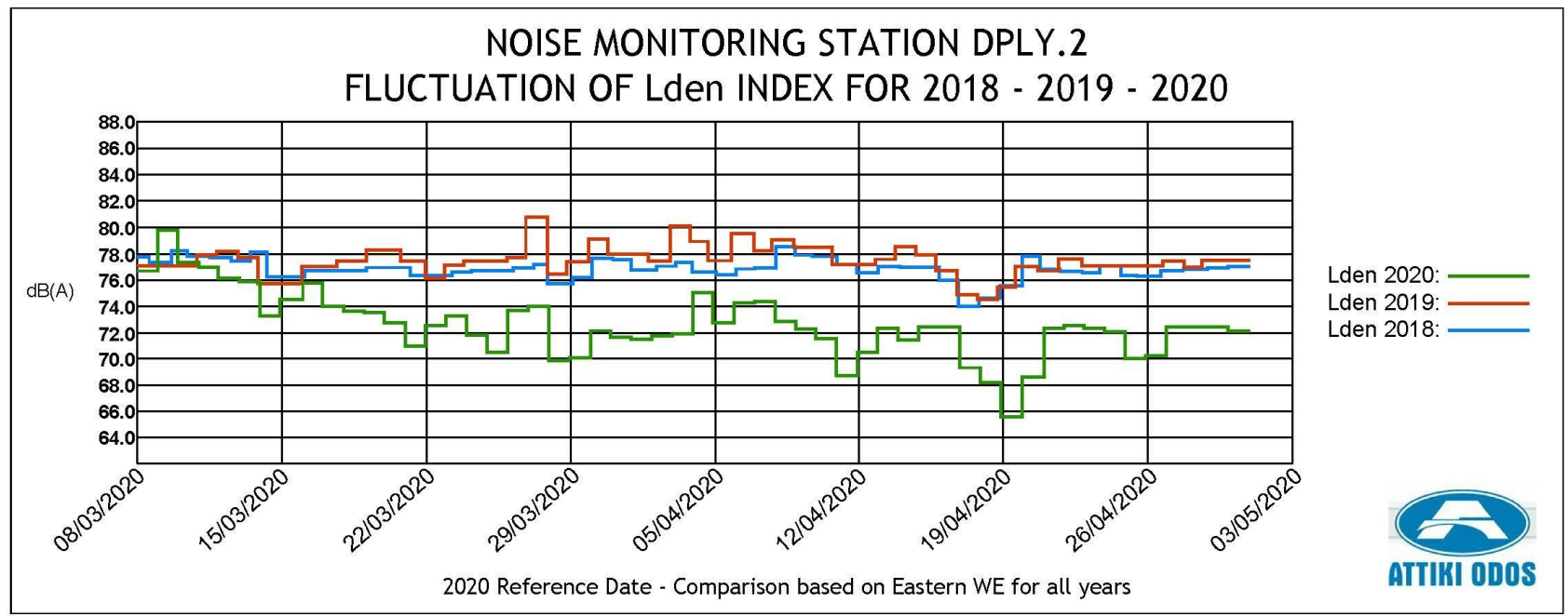

Figure 9h: Fluctuation of $\mathrm{L}_{d e n}$ index - Noise monitoring station DPLY.2

- The most important decline of traffic data was observed on 15 March 2020, the date of the start of the restrictive measures' implementation.

The important decrease of the road traffic volumes due to the restriction of population movement (lockdown) has significantly affected the environmental noise climate in urban settlements located in the proximity of the motorway. The relevant recordings of the permanent noise monitoring stations confirm the reduction of noise levels stemming from Attica Tollway. In the figures below the fluctuation in the 24-hour $\mathrm{L}_{d e n}$ index for the years 2018, 2019 and 2020 is presented for all 8 permanent monitoring stations.

Observing the graphs above, the following are concluded:
- Environmental road noise level fluctuation confirms that the noise climate of the years 2018 and 2019 shows no significant variations

- On the contrary, for the year 2020, the significant reduction of the road traffic has positively affected the noise climate for the period under consideration. The relevant $\mathrm{L}_{d e n}$ noise levels are some 3 to $6 \mathrm{~dB}(\mathrm{~A})$ lower compared to previous years 2018 and 2019.

- The maximum decrease was observed at the stations A14 and DPLY.1 around $6 \mathrm{~dB}(\mathrm{~A})$ which are affected from road traffic from and towards the airport. 


\section{The influence of COVID-19 disease: Aircraft noise}

Since many coronavirus cases in the early days were related to people who traveled abroad, the national government decided to suspend almost all international flights with only some government operational exceptions. The suspension of almost all international flights significantly affected the noise climate in the airport district as well as the neighboring settlements. Figure 10 hereafter shows the total number of flights between 9 March and 30 April 2020 for the years 2018, 2019 and 2020 as well as the total coronavirus cases in Greece. The figure fluctuation data confirm the important decrease of daily flights in 2020 during the period of implementation of restrictive measures because of COVID-19 disease. In the second instance, the curve showing the coronavirus cases is stabilized by the end of March and tends to be practically horizontal by the end of April. The suspension of mainly the international flights was therefore quite effective in reducing the spread of the virus.

The significant reduction of the air traffic (flights), as expected, had a positive impact on the environmental noise climate of the wider area of the airport, as per the recorded noise data of the permanent noise monitor- ing system (NOMOS). In the following figures the fluctuation of 24-hour $\mathrm{L}_{d e n}$ index of the most representative monitoring stations for the years 2018, 2019 and 2020 is presented. It is noted that for the creation of the graphs again the Orthodox Easter WE for year 2020 was set as the reference year for all previous years. It should be also noted that during the restrictions the eastern runway $(03 \mathrm{R} / 21 \mathrm{~L})$ for take-offs and landings was the sole operation RW from 27 March 2020 and towards (with only some minor exceptions for maintenance reasons) and for this period the existing noise abatement procedures were postponed.

It is noted that:

- The recordings of the permanent noise monitoring system were positively affected by the suspension of international flights

- The effects on the environmental noise climate in settlements adjacent to the airport were quite positive for the restrictions period under consideration

- The most important reduction of noise level is observed at the station NMT 8 , ranging from 8 up to $10 \mathrm{~dB}(\mathrm{~A})$.

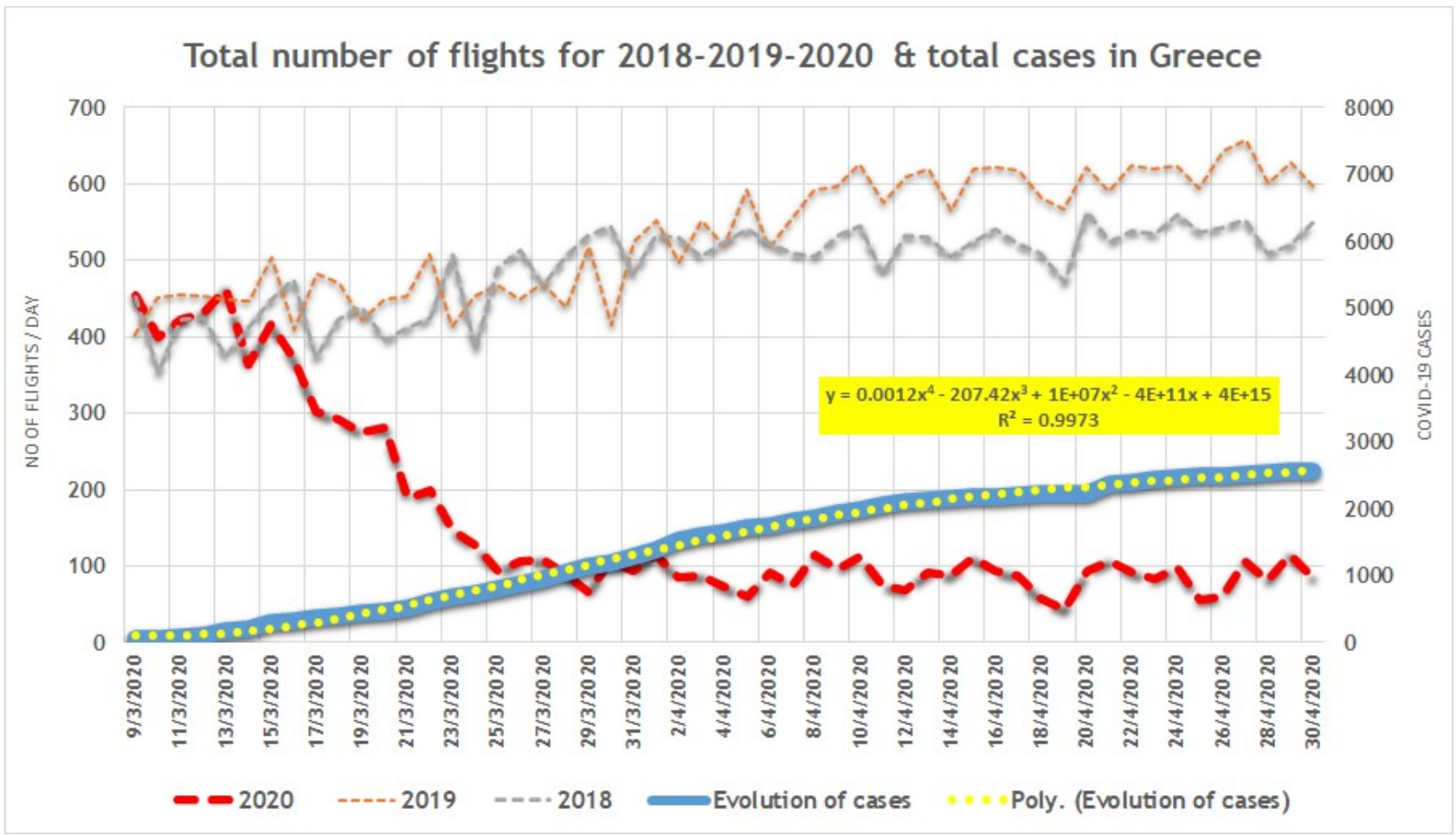

Figure 10: Total number of flights and total coronavirus cases 


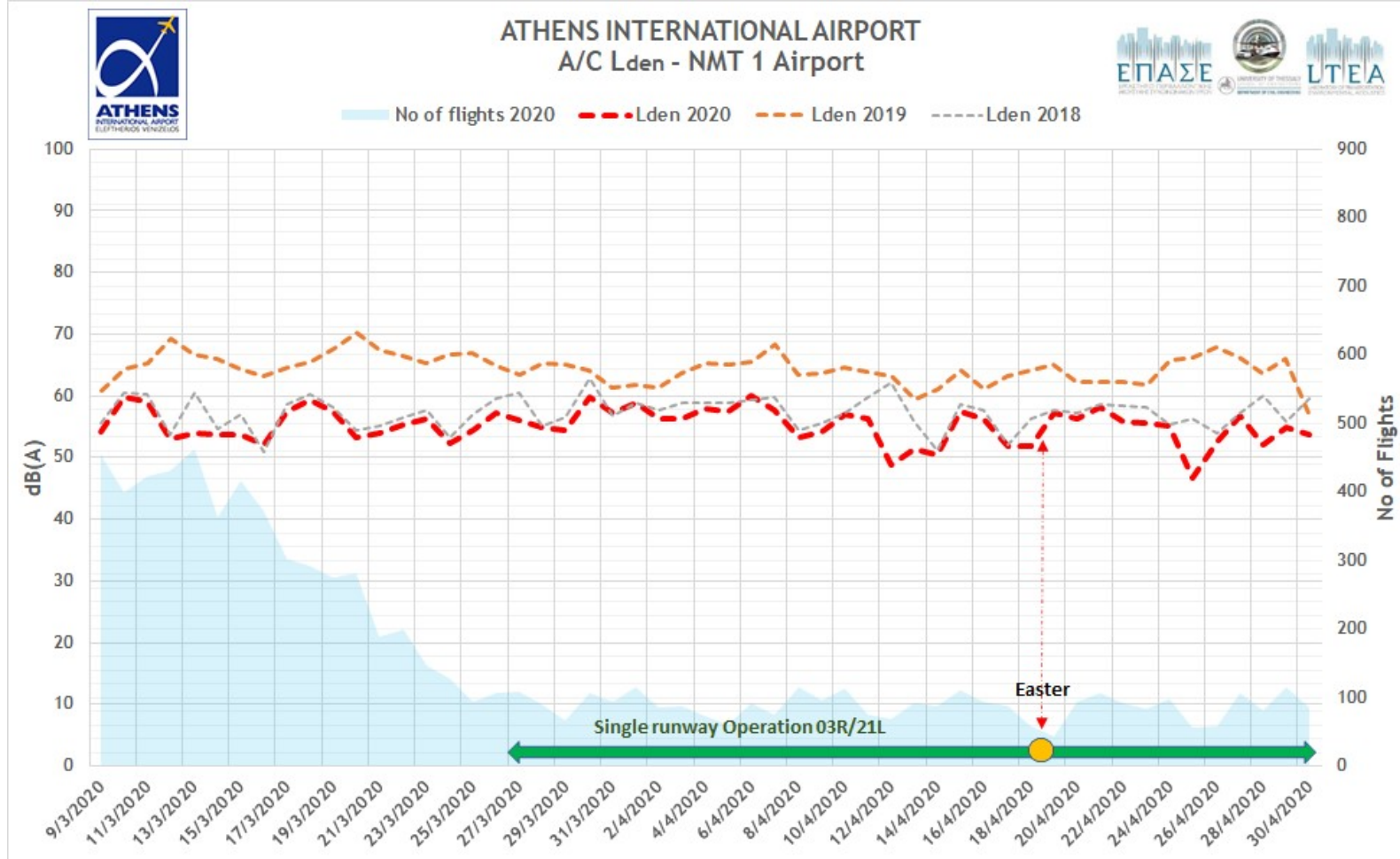

Figure 11a: Fluctuation of $L_{d e n}$ index - Noise monitoring station NMT 1 (Airport)

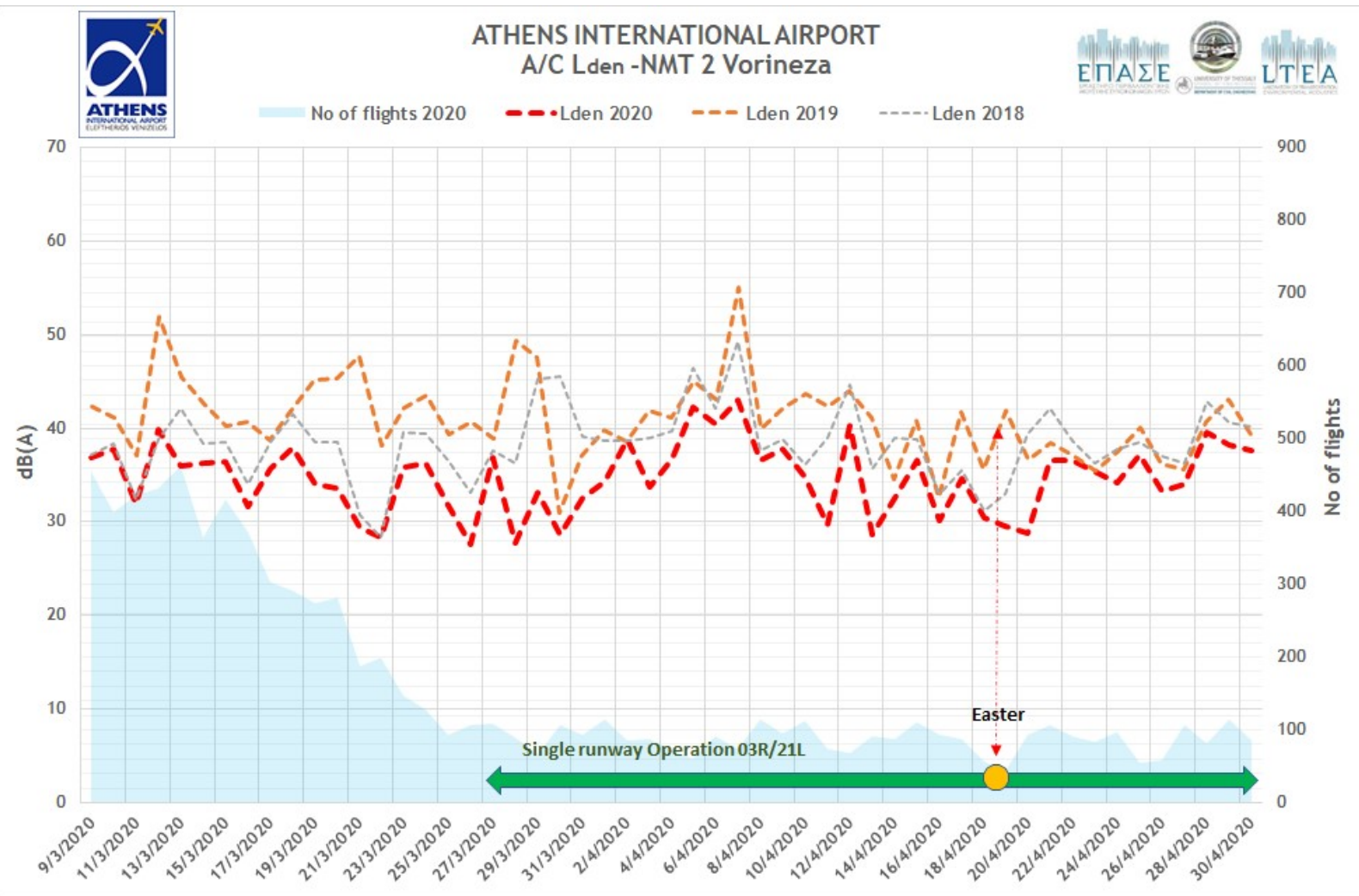

Figure 11b: Fluctuation of $\mathrm{L}_{d e n}$ index - Noise monitoring station NMT 2 (Vorineza) 


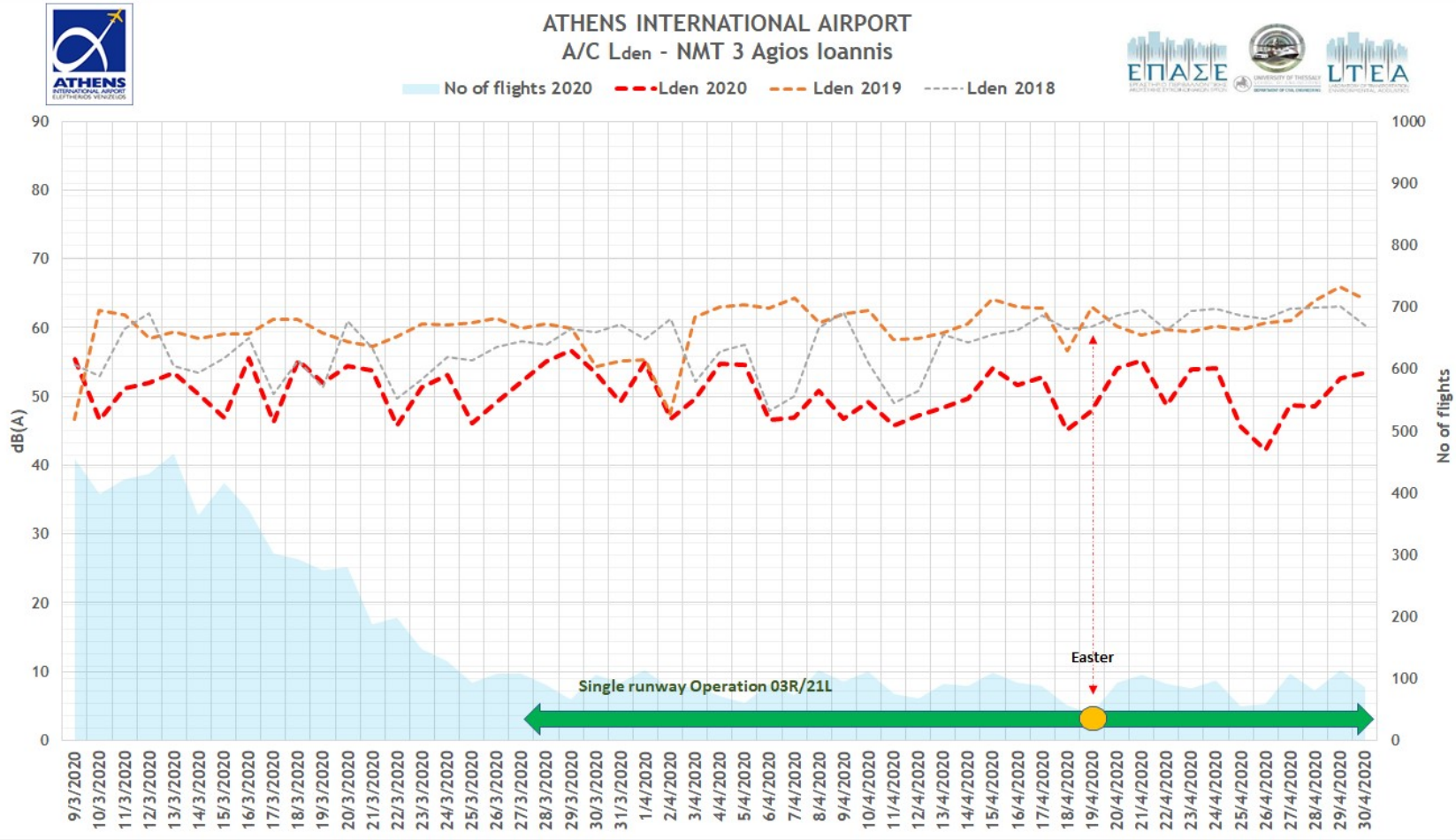

Figure 11c: Fluctuation of $\mathrm{L}_{\text {den }}$ index - Noise monitoring station NMT 3 (Agios loannis)

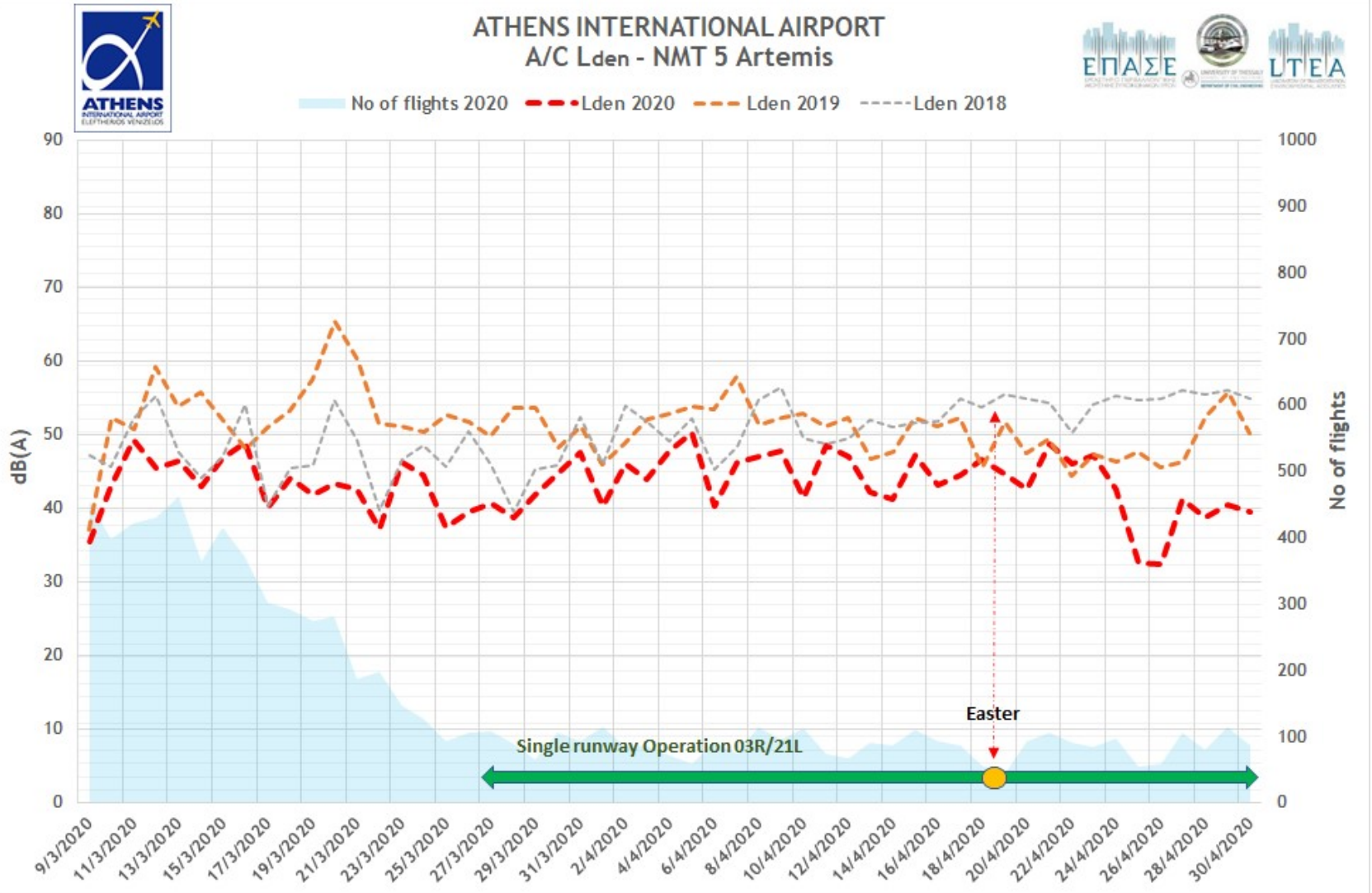

Figure 11d: Fluctuation of $\mathrm{L}_{d e n}$ index - Noise monitoring station NMT 5 (Artemis) 


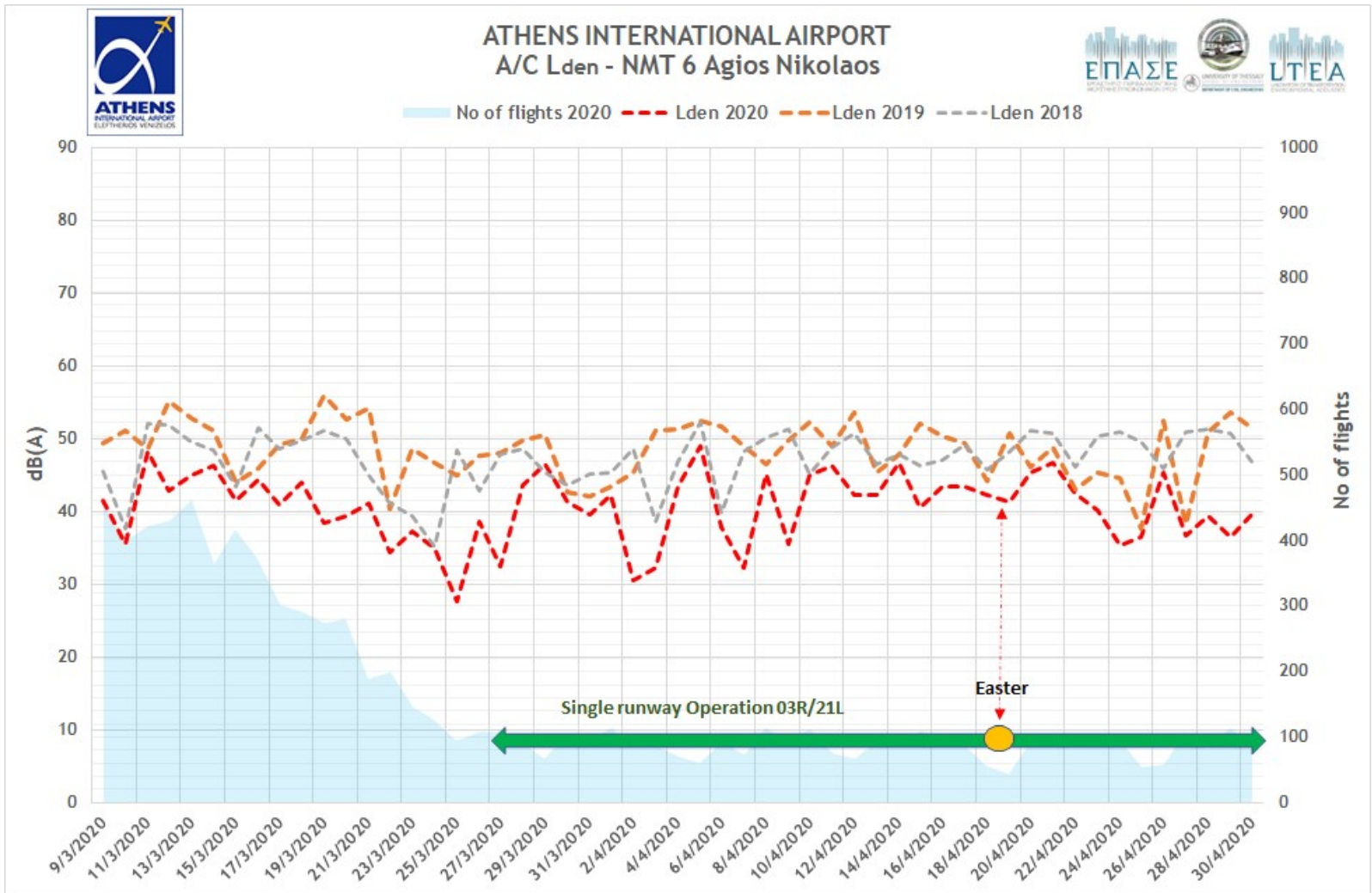

Figure 11e: Fluctuation of $L_{d e n}$ index - Noise monitoring station NMT 6 (Agios Nikolaos)

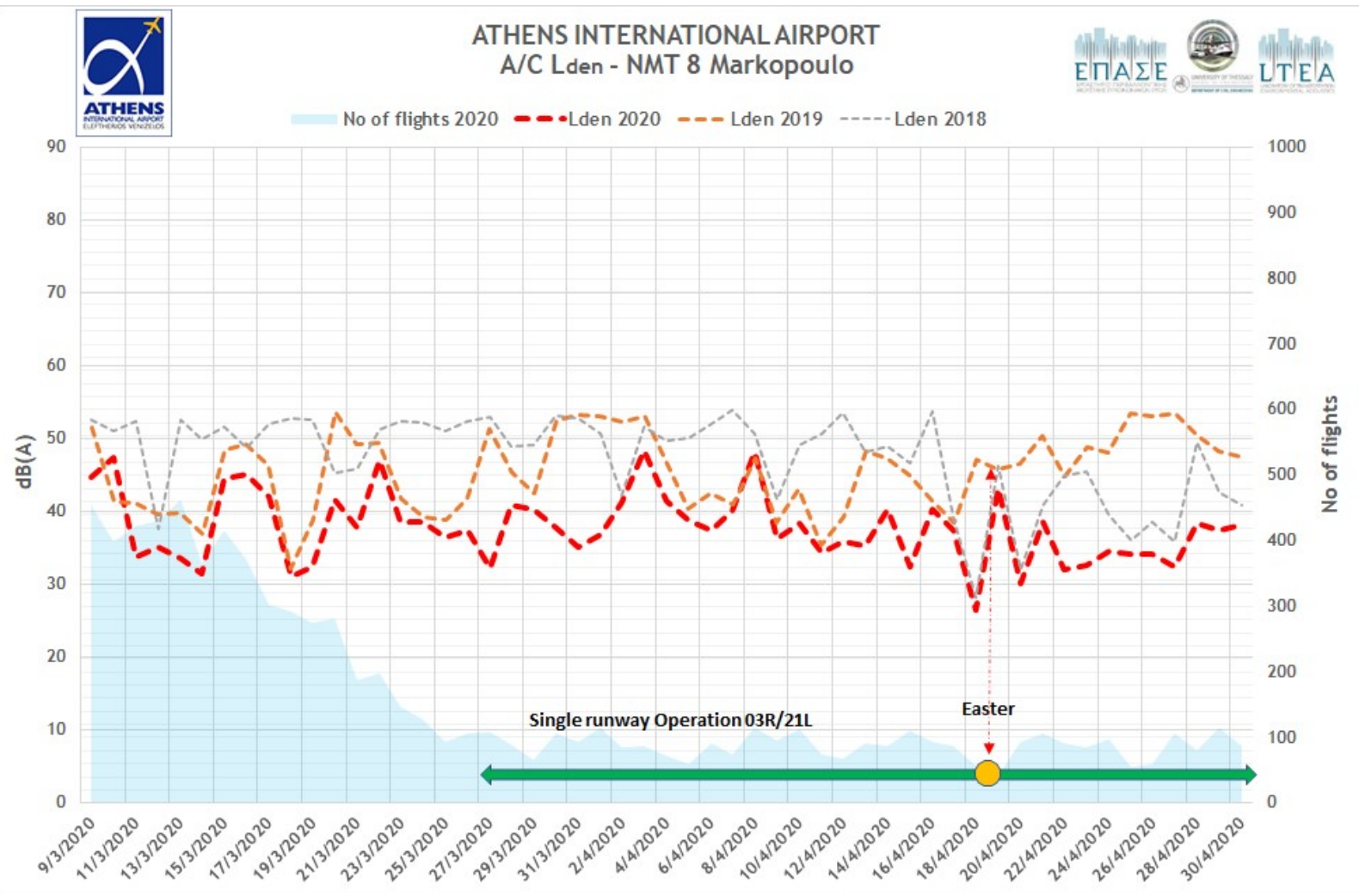

Figure 11f: Fluctuation of $\mathrm{L}_{d e n}$ index - Noise monitoring station NMT 8 (Markopoulo) 


\section{Conclusions}

The pandemic of COVID-19 disease has significantly affected many sectors of the society structure worldwide, such as public health and the economy. To effectively encounter the spread of coronavirus, national governments decided to implement a series of severe restrictive measures. In Greece, one of the most important restrictive measure implemented, was the suspension of both road traffic and international air traffic. The decrease of road traffic and the suspension of air traffic have significantly affected the noise climate in greater Athens area. Two major transportation projects in Greece, the Attiki Odos (Attica Tollway) and the Athens International Airport, were accessed regarding the noise climate quality during the pandemic. In particular, both permanent noise monitoring systems installed at the Athens International Airport and the Attiki Odos Motorway were used for the estimation of the fluctuation of the urban noise climate. According to the results of the European index $\mathrm{L}_{d e n}$, the following conclusions are drawn:

- The implementation of traffic restrictive measures due to COVID-19 disease influenced the noise climate as environmental noise emissions were significantly decreased

- In the case of Attiki Odos (Attica Tollway), the noise climate in the urban areas adjacent to the motorway was reduced from 3 to $6 \mathrm{~dB}(\mathrm{~A})$ for all noise monitoring stations

- In the case of A.I.A., the noise climate in urban areas adjacent to the Athens Airport was also significally decreased from 6 up to $8 \mathrm{~dB}(\mathrm{~A})$ also for all noise monitoring stations

- The suspension of international air traffic seems to have a most important impact on the environment noise climate than the restriction of the road traffic.
Conflict of Interests: The authors declare no conflict of interest regarding the publication of this paper.

\section{References}

[1] https://www.airport-athens.com

[2] Vogiatzis V., Dimitriou D., Konstantinidis A., Gerolymatou G., The Noise Action plan in the Athens International Airport (A.I.A) Eleftherios Venizelos - Evaluation of rules and procedures regarding noise relating measures and restrictions within a balanced approach, Paper presented at $26^{\text {th }}$ Int. Congr. Sound Vibr. ICSV 2019, July 7-11, 2019, Montréal, Canada.

[3] Vogiatzis V., Dimitriou D., Gerolymatou G., Konstantinidis A., Strategic noise mapping in Athens International Airport: A tool for balanced approach \& health effects evaluation, Noise Mapp., 2020, 6, 87-98.

[4] Vogiatzis V., Assessment of environmental noise due to aircraft operation at the Athens International Airport according to the 2002/49/EC Directive and the new Greek legislation, Appl. Acoust., 2014, 84, 37-46.

[5] https://ellaktor.com/en/activity/attiki-odos-aktorparachoriseis/

[6] Vogiatzis K., Zafiropoulou V., Implementation of Noise Barriers in Attiki Odos Motorway based on the relevant Strategic Noise Mapping and Noise Action Plan, Paper presented at Euronoise Conference, (Crete, Greece), 2018, 1175-1180.

[7] Vogiatzis K., Strategic environmental noise mapping \& action plans ring road (Attiki Odos)-Greece, WSEAS Trans. Environ. Develop., 2011, 7(10), 315-324.

[8] Sotiropoulou A., Karagiannis I., Vougioukas E., Ballis A., Bouki A., Measurements and prediction of road traffic along high-rise building façades in Athens. Noise Mapp., 2020, 7(1), 1-13.

[9] Licitra G., Gagliardi P., Fredianelli L., Simonetti D., Noise mitigation action plan of Pisa civil and military airport and its effects on people exposure, Appl. Acoust., 2014, 84, 25-36.

[10] Directive 2002/49/EC of the European Parliament and of the Council of 25 June 2002 relating to the assessment and management of environmental noise, Oflc. J. Europ. Commun. EU L 189/12, 2002.

[11] Vogiatzis K., Remy N., Strategic noise mapping of Herakleion: The aircraft noise impact as a factor of the Int. Airport relocation, Noise Mapp., 2014, 1(1), 15-31.

[12] JMD 211773-Official Gazette B-1367 of 27-04-2012. 